\title{
RINGING IN THE CHANGES
}

Papers presented at a symposium with the objective to give information on the interpretation and implementation of the S.A. Nursing Council regulation and directive R2118 of 30 September 1983.

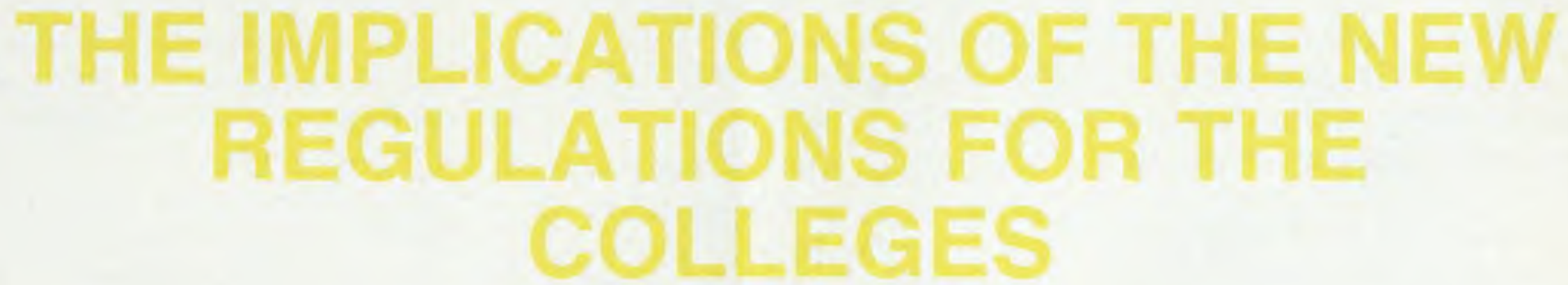

NORMA V PAVERD

\section{OPSOMMING}

'n Positiewe houding by alle verpleegkundiges is die sleutel tot die veranderinge wat die nuwe opleidingsregulasies meebring.

Die implementering van die nuwe regulasies vereis die toewyding en samewerking van die universiteit, kollege, hospitaal en verskeie staats -en plaaslike owerhede. Dus is die kollege nie die enigste besluitnemer in die kurrikulumproses nie en het ook nie die uitsluitlike reg tot onderrig nie — almal moet betrokke raak.

Die outonomie van kolleges impliseer status as 'n tersière onderrig-instansie. Dit impliseer egter nie onafhanklikheid nie.

Verant woordelikheid, outoriteit en outonomie impliseer verantwoordbaarheid binne die riglyne van die betrokke wetgewing.

Wat die student betref sal sy onder die nuwe stelsel voorsien word van doelwitte wat haar kan rig, sy sal aan verskeie leermetodes blootgestel word en deurlopende kliniese evaluasie sal aan haar terugvoer oor haar vordering gee.

\section{INTRODUCTION}

In particular, the objective of this presentation is to describe

- how the college structure and function will alter to enable the implementation of the new regulation

- the concept of autonomy and the legislation which has been passed in the Cape allowing autonomy

- give some indication of how the student's position will change.

Kahlil Gibran wrote Vague and nebulous is the beginning of all things, but not their end, . . . This positive view of change and its inevitable accompanying uncertainty is reflected in the history of the nursing profession in South Africa and, especially, in the era since Henrietta Stockdale.

Chaska writes Professionals who ignore differing perspectives may limit their growth. As caring professionals, we need to identify the salient questions even though the answers may not be readily available. We must strive not for just any answer but for the best answer to each situation and problem that arises in the profession. (3p xiii)
Regardless of the prosperity that may be present, one always has the company of uncertainty and, therefore, a degree of risk and insecurity. It is not this degree of uncertainty and risk that enables us, in life, to experience an exciting sort of expectancy?

\section{A CHANGE OF ATTITUDE}

Discard fear and make a grand entrance with the stimulus of the unknown to spur you on to being prepared to take up the challenge to achieve the highest professional standards. The key to ringing in the changes is attitude.

The single most important factor in this entire issue is a critical look at our roles! The role of the clinical professional nurse, the role of the nurse administrator and the role of the nurse educator. It is not the intention to expound upon this any further but an honest appraisal of what we are actually doing in relation to what we know we should be doing is the launching pad of our endeavour. The question to be asked is whether we have not paid lip service to the findings of research investigation and the consequent recommendations for long enough?
We all know about Blooms taxonomy but do we all use it, apply it? Coetzee (1979 p 4) puts it in a nutshell when she refers to Pullias ... effectiveness depends upon a clear and developing concept of that role, personality traits of a special order, much professional knowledge, many highly developed skills, and a particular art that expresses itself in a special style. She is referring to teacher effectiveness, but this surely applies to all of us! This change in attitude is not confined to the educators only, but also to the administrators and the clinical practitioners.

The changes that we are facing today heavily accentuate another aspect that many of us also pay lip service to - the mere fact that all nurses are teachers! Coetsee (1979 p 4 et. seq.) highlights the most necessary universal traits of the great teacher from Pullias as follows:-

- Integrity and authenticity: a freedom from phoniness or pretence, an approach to genuineness and utter sincerity.

- Enthusiasm and zest: an ardent belief in the significance of what one is doing and the energy to put life into it. 
- Directness or nearness to reality: an almost childlike relation to things and people, an elemental quality of immediacy that escapes the deadened heavy hand of pedantry and over-abstraction.

- Perspective and length and breadth of view: manifested frequently in a sense of humour, patience, freedom from the scourge of perfectionism.

- Freedom of mind, especially freedom of imagination, an eagerness to consider many alternatives.

- Breadth of interest, and a sensitivity to a wide spectrum of life: manifested in wide reading and varied concerns.

- An abiding concern for the individual learner: an ability to feel and communicate the notion that the individual learner is significant, that he has potential of great worth and that it can be realised.

\section{Clinical practice}

There is a further issue that needs to be examined realistically by the nurse who no longer, by virtue of her present role, has direct clinical involvement. The statement present role is accentuated because the author believes it must change.

Professor Mitchell of the University Hospital, Nottingham, in his debate on the nursing process touches on an issue that has a major implication for the success of our new curriculum. He refers to the exclusion of doctors in the teaching of nurses, not that this is being done to any great extent in South Africa and this is not the issue at stake but he says -

"In my view the background and training of the nurse teachers does not allow them to act as substitutes for doctors in the teaching about diagnosis and outcome. More over, teachers in clinical medicine continue to practice their medicine, surgery, obstetrics or the like, where as most nursing teachers have had to cease to be practising nurses. In many hospitals there is thus a considerable gap between what the ward sisters would like to see taught and what is actually taught in their nurse training schools." (Bold, author's own) (1984 p 217).
This issue lies at the nucleus of the title of this paper. It has a major implication for the college. We must devise a way of returning to clinical practice - not to clinical teaching only - but to clinical practice. Something else to pay lip service to? We dare not - we must work with our students and not over them!

In dealing with the other issues included, never lose sight of the attitude change that is at the nucleus of the changes that lie ahead.

\section{ALTERATION IN THE STRUCTURE AND FUNCTION OF THE COLLEGE}

\section{The training complex}

A new curriculum is required and it is not the intention to go into curriculum design here but before curriculum design can be initiated onc vital change is essential. The implementation of the new regulation cannot take place without the commitment of the university, the college, the hospital and the various State health and local authorities it is, therefore, vital to view these elements as a training complex. This entire complex is involved in the achievement of the goal. So at the baseline is a systems approach. A system according to Gillies is a set of objects or elements in interaction to achieve a specific goal. (1962 p 56) The training complex must be the point of departure, and this complex includes the various elements as mentioned above.

When curriculum design starts, therefore, each of these elements is in interaction and is an inexpendable part of the team. This simply means that the members of the curriculum design team must be the representatives of each of the elements in the training complex. Each member in turn consults with and provides feedback to the particular institution or authority involved.

The college, therefore, cannot be the sole decisionmaker as regards the curriculum. This is one critical change that must become an accepted fact. We must see ourselves as inexpendible to the other. Janet
Rogers in Berger et al writes about the change process and in referring to the change agent maintains 1.l. Ithe most singular skill of the successful change agent is that of interpersonal competence. The interpersonally competent individual is healthy, intelligent, emphathetic, autonomous, sound in his judgements and innovative. He is the kind of individual who can size up a situation, maintain an awareness of the human factors involved, and develop a diagnostic sensitivity as well as behavioural flexibility in dealing with human problems. (1980 p 203)

We must emerge now from our cocoons in which we were so comfortable. Can the nurse educator reserve the exclusive right to teach anatomy? The clinical practitioner has the same knowledge base and therefore the ability to develop it further to enable her to teach anatomy just as well as anybody alse Given the same objectives as the tutor in the college, she can lead the student to achieve them just as effectively. The training complex must develop reciprocal trust in their ability to train the student.

The good old "Block system", that has served us well, must go! The clinical instructor, the chief professional nurse in the college and the chief professional nurse in the hospital and, for that matter, all professional nurses, must be welded into a teaching community which focuses upon the aspiring professional nurse. What about the hospitals in the periphery - those which are kilometers away from the college? Given the same objectives as the tutor in the college, the professional nurse in the clinical setting, the ward sister and for that matter the clinical instructor can lead the student to achieve the objectives just as effectively.

Do not underestimate your colleagues. Rather evaluate, redesign and amend the curriculum. the objectives, the study guides, the training modules. Rather act as leader. co-ordinator, researcher, innovator and change-agent in the training of the student. Give up this exclusive teaching right and do those things that your specific educational preparation enables you to do. 


\section{Teaching methods}

No single method in teaching the student must be discarded. But do not overutilise the one to the detriment of the others. One cannot deny the rightful place of the didactic lecture, but use the other teaching methods as well. Learning must be done by the learner. Teaching is not just telling. The individual needs of the student demand flexibility and adaptation. We must use educational technology, the autotutorial system of instruction as well as the legion of other methods at our disposal. This is the specialised and more exclusive terrain of the nurse educator.

Professor Williamson highlights this when she maintains $I t$ is in the informal situation that nurses realise their professional function; in small group discussions, in face-to-face contacts. These situations are the media for professional growth and enrichment... Nursing education should offer meaningful learning experiences, and it is the practical setting which gives meaning to the theoretical component. (1978 p 14)

\section{Communication}

The concept of a training complex or a training community is underpinned by another vital issue - that of communication. The components, elements and/or, if preferred, people involved in the training complex are not necessarily in close proximity to each other. The limitations and barriers of the situation, such as spatial distance, must be overcome so that information exchange, consultation and negotiation can take place meaningfully without misconception and confusion which may provoke resistance to change due to insecurity and fear of instability. Ensure that all those involved know what is happening so that they might provide valuable inputs and be committed to the new system.

\section{Student administration}

The present organisational structure of the college need not change radically within a short period of time, on condition that the concept of a training complex is accepted.
Although a long term goal it will be a virtual impossibility - financially, structurally and logistically to uplift student education administration personnel (that is matrons and clerks in administration of student affairs) and place them into the college simply because the college is to register students and account for training instead of the hospital. The same applies to clinical teaching departments within hospitals. The process will have to be gradual in transition. Here specific reference is being made to the larger training institutions, although the smaller training hospitals are also involved.

What is important, however, is that student education administration aspects should be experienced by college personnel. They should be seconded into the hospitals to work in student administration for a least six months. This should be done now while the three-and-a half year courses are being phased out. An interchange of personnel is desirable and initially the tutors and clinical instructors should be the focus.

\section{CONCEPT OF AUTONOMY AND LEGISLATION}

\section{Legislation}

Legislation in the Cape in the form of the Training of Nurses and Midwifes Ordinance, 1984 (Ordinance 4 of 1984), makes provision for the establishment and control of nursing colleges for the training of nurses and midwives and for matters incidental thereto.

The content, in brief, is as follows:

- Definitions: Nursing college means an educational institution in which courses leading to a diploma or certificate or a diploma and a certificate are offered in the various ramifications of nursing on a basic and postbasic level,

training institution means any hospital or other institution, organisation or service with facilities for the provision of training for students attached to a nursing college or university.

- Establishment and maintenance of nursing colleges.

- Connection of training institutions with nursing colleges.
- Courses and examinations The Administrator shall, with the approval of the South African Nursing Council as contemplated by section 2 of the Nursing Act. 1978 (Act 50 of 1978) introduce such curricula for students at nursing colleges as he may deem necessary from time to time, and shall provide for the training of and the sitting for examinations by such students.

- Admission of students to nursing colleges.

- College council.

The Administrator shall constitute a college council for the management and administration of a nursing college, and the college council shall exercise such powers and perform such duties as may be determined by the Administrator.

- College senate.

The Administrator shall constitute a college senate which shall function under the authority of the college council, as contemplated by section $6(1)$, and the college senate shall exercise such powers and perform such duties as may be determined by the Administrator.

- Regulations.

The Administrator may make regulations which are not in conflict with the provisions of this Ordinance for the better implementation of the provisions and generally to promote the objects thereof

- Repeal of Ordinance.

- Short title and date of commencement. (1984)

Legislation, that is, the above Ordinance read with due consideration of the provisions of the South African Nursing Council Regulation R2118 of 30.9 .1983 requires that the college draw up a document which will provide the following information:

- College facilities.

- Facilities for clinical learning experiences for the diploma for registration as a nurse and a midwife. This will include all training institutions (refer to the definition of training institution). 
- Facilities. Support systems and other aspects such as social facilities, sport, religion, student counselling, study guidance. health facilities.

- Teaching personnel - which includes names and qualifications of each member of the training institution as well as the college personnel.

- System of training, evaluation and examination. This includes:

- the curriculum and a plan for its implementation providing for the requirements of the S.A. Nursing Council regulation (R2118) and the directive

- the examinations; including security, setting of papers, marking of papers, moderation of papers, the results, the re-write, examination timetables and examination regulations.

- Committees, such as

- student selection and allocation committee

- curriculum committee

- examination committee

- disciplinary committec.

The members and the proposed powers and duties of each committee.

- College Council -- the members and their proposed powers and duties.

- College Senate - the members and their proposed powers and duties.

This document must be accepted by the head of the department of nursing science at the university of proposed affiliation.

The document is then submitted to the Director of Hospital Services and thus for the approval of the Administrator. The affiliation is then formally negotiated between the provincial administration and the university, the Minister of Health and the S.A. Nursing Council for final approval. An agreement is also negotiated with the Department of Health and Welfare and local authorities.

\section{Role of college}

Functionally then, the college has a leading role through its council in:

- determining of policy, management and administration
- the control of its own budget and those aspects that involve finance

- personnel administration

- teaching facilities

- controliing basic and post-basic education and negotiating with the S.A. Nursing Council.

- student selection, registration and allocation

- curriculum design

- examinations, written and practical

- records and documentation of training

- disciplinary matters.

None of these functions are however confined to the college personnel. All the components of the training complex are intimately involved by virtue of the establishment of committees, the university faculty serving as the moderator throughout.

\section{Autonomy}

At this point one must consider the question of autonomy. Autonomy of a college implies that it is granted a status equal to that of a tertiary educational institution. The Concise Oxford Dictionary defines autonomy as the right of self government and as personal freedom (11 p 79).

Batey and Lewis undertook a study to achieve greater clarity about the concept autonomy, from a clinical practice and administrative point of view. The authors found that responsibility, authority and autonomy are pre-conditions for accountability. They found that $A$ responsibility is a charge for which one is answerable. We must be careful not to confuse responsibility with the state of being responsible. While responsibility denotes a charge, being responsible or having a sense of responsibility is the acceptance of a charge. Authority is the rightful (legitimate) power to fulfil a charge. Autonomy is used variably in the literature to mean self determination, self direction, freedom to design a total plan of care and to interact on an interdependant level with other professionals, . . . and independance (1982 p 13 et seq).

... a definition of autonomy. freedom to make discretionary and binding decisions consistent with one's scope of practice and freedom to act on those decisions . . . Ones scope of practice denotes the workrelated boundaries within which dis. cretionary and binding decisions and actions would occur. Including scope of practice in the definition distinguishes autonomy from absolute independance. Autonomy is confined to that for which the professional holds authority derived from expert knowledge and position (1982 p 13 et seq)

The work-related boundaries and the scope of practice are the focus in our situation. The main consequence of autonomy in this case and possibly in all cases is accountability. The responsibility, authority and autonomy in the context of the changes that we are referring to must be in congruence with the goals of those authorities that have given us the freedom to make decisions and therefore implies that we must account for our actions. We have an Ordinance and S.A. Nursing Council regulation that provide the boundaries within which we may move. The training complex and, more specifically, the college must be accountable to the university who will act as the moderator

\section{HOW WILL THE CHANGES AFFECT THE STUDENT?}

The author would like to think as Chaska does It is hoped that the student cannot only be taught nursing but also that she or he can be given motivation to live fully and deal with life's problems, tribulations and happy events. The professional role is not enough. We need the insightful candidate who can realistically adapt to change and establish her own talent for originality and creativity. Just as patient care includes social and emotional consideration, so too must the teaching or nursing students. The student must be prepared socially and emotionally as well as academically if she is to meet her professional challenges ( 3 p 33 ).

In her first year the student should, with adequate curriculum design, be accompanied directly by the training team - tutor. ward sister, clinical instructor. departmental matron - in achieving the objectives of the introduction to nursing science which will provide the basis for the years that will follow. Continued on p. 19 